УДК: 001.8:[005.334.658.15:657.635]

JEL Classification: C6; M 42

C. В. СЕЛIЩЕВ,

кандидат економічних наук, асистент Національного иентру обліку та аудиту, Національна академія статистики, обліку та аудиту

\title{
Використання математичних моделей при проведенні аудиту дотримання принципу безперервності діяльності підприємств
}

В статті здійснено огляд та систематизацію найбільи поширених факторних математичних моделей аналізу фінансового стану підприсмства, методик йх застосування та оцінки показників. Досліджено можливість адаптацій існуючих методик застосування математичних моделей при проведенні аудиту дотримання принципу безперервності діяльності підприсмств. В результаті дослідження визначено найбільи оптимальний набір математичних моделей виходячи з вимог поточной практики аудиту.

Ключові слова: припуцення про безперервність, аудит, аудиторськиї ризик, математичні моделі.

Постановка проблеми. Нестабільність економічної ситуації в цілому та відсутність досвіду роботи за нових умов кардинальної зміни зовнішнього та внутрішнього торговельно-економічного курсу України призвели до виникнення і поширення кризових явищ на вітчизняних підприємствах. Зважаючи на це при проведенні аудиту необхідно перш за все звертати увагу на адекватність використання припущення про безперервність діяльності підприємства при нідготовці фінансових звітів з боку управлінського персоналу.

Це обумовлює потребу в перегляді існуючих методик та розроблення нових методологічних концепцій ідентифікації ключових показників функціонування нідприємства та аналізу їх критичних значень, необхідних для оцінювання ймовірності припинення діяльності в осяжному майбутньому при застосуванні математичних моделей.

Аналіз досліджень і публікацій. Актуальності у цьому сенсі набувають дослідження, спрямовані на подальше розроблення та адаптацію методології застосування математичних моделей аналізу фінансового стану нідприємства, висвітлені у працях вітчизняних та зарубіжних вчених $[1 ; 2 ; 7]$, та загальнонаукові організаційнометодичні підходи до проведення аналітичних процедур щодо отримання аудиторських доказів використання управлінським персоналом припущення про безперервність діяльності нідприємства при нідготовці фінансових звітів [3-6; 8-10].

Метою статті $є$ дослідження та систематизація існуючих методик, а також розроблення методології застосування факторних математичних моделей при оцінюванні ризику припинення діяльності нідприємства.

Внклад основного матеріа уу дослідження. В ході проведення системного та комплексного дослідження фінансового стану суб' єкта господарювання шляхом застосування математичних моделей можна дійти попередніх висновків щодо присутності ризику припинення діяльності на основі інформації, що міститься у фінансовін̆ звітності.

У практиці аудиту застосовується досить широкий спектр аналітичних процедур, основаних на використанні методик прогнозування платоспроможності та ризику банкрутства суб'єктів господарської діяльності, що перевіряються.

При проведенні аудиту необхідно обрати методику, яка б відповідала таким критеріям:

- відповідність галузі суб'єкта господарювання;

- відповідність наявній інформаційній базі;

- адекватність масштабу бізнесу суб'єкта перевірки та часу, виділеного на застосування такої методики.

(C) С. В. Селіщев, 2017 
Аналіз вітчизняних і закордонних наукових джерел, присвячених методикам прогнозування економічного стану підприємства, свідчить, що найбільш поширеними 3-серед них є такі:

1) визначення коефіцієнта поточної ліквідності;

2) визначення коефіцієнта швидкої ліквідності;

3) модель Бівера:

4) двофакторна модель Альтмана;

5) п'ятифакторна модель Альмана;

6) модель Спрінгейта.

Для визначення ефективності та доцільності застосування згаданих моделей при проведенні аудиторсыких процедур оцінювання ризику припинення діяльності слід розглянути їх більш детально.

Коефіцієнт поточної ліквідності показує здатність компанії погашати поточні (короткострокові) зобов язання за рахунок тільки оборотних активів. Чим більше значення коефіцієнта, тим краше платоспроможність підприємства. Цей показник враховує, що не всі активи можна реалізувати в терміновому порядку.

Загальна формула розрахунку коефіцієнта поточної ліквідності:

Ктл = Оборотні активи / поточні зобов'язання.

Нормальним вважається значення коефіцієнта $1,5-2,5$, в залежності від галузі економіки. Значення нижче 1 вказує на високий фінансовий ризик, пов'язаний із тим, що підприємство не в змозі стабільно оплачувати поточні рахунки. Значення більше 3 може свідчити про нераціональну структуру каніталу [2, с. 87]. Якщо значення менше 1,5 , це вказує на проблеми покриття поточних зобов язань та необхідність скорочення кредиторської заборгованості. При відсутності прогнозованих шляхів скорочення кредиторської заборгованості цей показник може свідчити про існування суттєвого ризику припинення діяльності нідприсмства.

Коефіцієнт швидкої лікві дності - фінансовий коефіцієнт, що дорівнює відношенню високоліквідних поточних активів до короткострокових зобов язань (поточних пасивів). Даними для його розрахунку служить бухгалтерський баланс компаніі. На відмгіну від поточної ліквідності, в складі активів не враховуються матеріально-виробничі запаси, оскільки при їх вимушеній реалізації збитки можуть бути більше, ніж при реалізації інших оборотних коштів.

Загальна формула розрахунку коефіцієнта швидкої ліквідності:

Кбл = Короткострокова дебіторсыка заборгованість + Короткострокові фінансові вкладення + Грошові кошти / Поточні зобов'язання.

Коефіцієнт швидкої ліквідності - це більш жорстка оцінка ліквідності нідприємства. Цей коефіцієнт також називається “кислотним тестом", і розраховується він з використанням тільки частини поточних активів - грошових коштів, легко реалізовуваних цінних паперів і дебіторської заборгованості, які зіставляються 3 поточними зобов'язаннями.

Цей коефіцієнт показує можливість погашення поточних зобов'язань, якщо становище $\epsilon$ дійсно критичним, виходячи з припущення, що товарно-матеріальні запаси взагалі не мають ліквідаційної вартості. Шоб правильно оцінити цей коефіцієнт, необхідно встановити якість цінних паперів і дебіторської заборгованості.

Покупка сумнівних паперів і збільшення кількості сумнівних дебіторів можуть призвести до завищеного значення коефіцієнта швидкої ліквідності, що створить сприятливе враження про становище компанії. Але існує висока ймовірність того, шо при продажу таких цінних паперів компанія зазнає збитку, а дебіторська заборгованість не буде виплачена взагалі або ж буде погашена через досить великий промгіжок часу, що рівнозначно невиплаті.

Нормальне значення коефіціснта швидкої ліквідності знаходиться в діапазоні 0,7-1. Однак воно може виявитися недостатнім, якщо велику частку ліквідних коштів становить дебіторська заборгованість, частину якої важко своєчасно стягнути. У таких випадках потрібне більш високе значення коефіцієнта [2, с. 88].

Якшо коефіцієнт швидкої ліквідності менше 0,7 , то кредити організації будуть видані під більший відсоток, або можлива відмова в кредитуванні, а також ризик втрати потенційних інвесторів, що, в свою чергу, є ознакою припинення діяльності нідприємства в осяжному майбутньому. 
Згідно із системою показників У. Бівера відношення чистого прибутку до суми боргу може визначити ризик банкрутства підприємства. Формула розрахунку цього коефіцієнта називається “формулою Бівера". Він займає головну позицюю в системі коефіцієнтів моделі Бівера, яка представлена нижче.

Головною відмінністю системи Бівера від інших систем діагностики банкрутства підприємства $\epsilon$ те, що в основним у ній $\epsilon$ інтегральний показник (якщо порівнювати 3 моделями Альтмана), а також не враховується вага кожного окремого коефіцієнта. Значення декількох коефіцієнтів порівнюються з нормативними величинами, і відповідно до них нідприємству присвоюється один із трьох станів:

1. Фінансово стійке.

2. Ймовірне банкрутство протягом п'яти років.

3. Можливе банкрутство протягом одного року (таблиця).

\section{Таблиця Бівера}

\begin{tabular}{|l|l|c|c|c|}
\hline \multicolumn{1}{|c|}{$\begin{array}{c}\text { Фінансовий } \\
\text { показник }\end{array}$} & \multicolumn{1}{|c|}{$\begin{array}{c}\text { Формула } \\
\text { коефініснта }\end{array}$} & $\mathbf{1}$ & $\mathbf{2}$ & $\mathbf{3}$ \\
\hline Коефіцієнт Бівера & $\begin{array}{l}\text { (Чистий прибуток + Амортизація) / } \\
\text { (Довгострокові + поточиі } \\
\text { зобов'язання) }\end{array}$ & $0,4-0,45$ & 0,17 & $-0,15$ \\
\hline $\begin{array}{l}\text { Коеффіцієнт } \\
\text { рентабельності } \\
\text { активів, \% }\end{array}$ & Чистий прибуток х 100/ Активи & $6-8$ & 4 & -22 \\
\hline $\begin{array}{l}\text { Коеффіцієнт } \\
\text { фінансового “важеля" }\end{array}$ & $\begin{array}{l}\text { (Довгострокові + поточиі } \\
\text { зобов'язання)/ Активи }\end{array}$ & $<0,37$ & $<0,5$ & $<0,8$ \\
\hline $\begin{array}{l}\text { Коеффіцієнт покриття } \\
\text { актпвів чистим } \\
\text { оборотним капіталом }\end{array}$ & $\begin{array}{l}\text { (Власний капітал - Необоротні } \\
\text { активи) / Активи }\end{array}$ & 0,4 & $<0,3$ & $-0,06$ \\
\hline Коеффіцієнт покриття & $\begin{array}{l}\text { Оборотні активи / поточні } \\
\text { зобов'язання }\end{array}$ & $<3,2$ & $<2$ & $<1$ \\
\hline
\end{tabular}

Джерело: [7, с. 128]

Однією з переваг шеєї моделі $є$ те, що припинення діяльності прогнозується як за кількісним характером, так і за терміном настання. Також модель містить значення зважених коефіцієнтів і ліміальних значень групових та індивідуальних показників. Основним ііі недоліком $\epsilon$ те, що наведепі в таблиці показники розраховано на базі даних лише американських нгддприємств. В цілому, економічний сенс моделі полягає в тому, що це функція, яка охоплює ряд кількісних показників і враховує їх вагу (значимість) в нідсумковій оџпнці.

Двофакторна модель Альтмана - найпростіша модель із існуючих. Охоплює два фінансових показника: коефіціснт поточної ліквідності та частку позикових коштів у пасивах. Формула двофакторної моделі Альтмана:

$Z=-0,3877-1,0736 *$ Ктл $+0,579 *(3 К / П)$,

де КТЛ - коефіцієнт поточної ліквідності; ЗК - позиковий кагітал; П - пасиви, а $Z$ - розрахунковий коефіцієнт, який вимгірює стунінь банкрутства.

Оџннка результату: при $Z>0$ констатується високий ризик банкрутства, $Z<0$ низыкий [7, с. 140].

Двофакторна модель Альтмана характеризується легкістю алгоритму розрахунків, ii можливо застосовувати при проведенгі зовншннього аналізу на базі даних бухгалтерського балансу. Але ця модель не враховус вплив коефіцієнтів, які визначають ефективність використання ресурсів, ділову і ринкову активнгість і т. д., а також сферу функціонування та географію розташування бізнесу.

П'ятифакторна модель Альтмана розроблена для оцінювання ймовірності банкрутства компаній, чнії акції торгуються на ринку. Є найбільш відомою моделлю цього автора. Формула п'ятифакторної моделі Альтмана:

$Z=1,2 \mathrm{X} 1+1,4 \mathrm{X} 2+3,3 \mathrm{X} 3+0,6 \mathrm{X} 4+\mathrm{X} 5$, 
де X1 - відношення оборотного капіталу до валюти балансу (визначає обсяг чистих ліквідних активів), X2 - відношення нерозподіленого прибутку (або непокритого збитку) до валюти балансу (відображас фінансовий важіль компаніі), X - відношення валового прибутку до валюти балансу (визначає ефективність діяльності компапіі), X4 - відношення вартості власного капіталу до вартості всіх зобов'язань, X5 - відношення обсягу продажів до валюти балансу (визначає фондовіддачу).

Оцінка результату:

Значення $Z<1,81$ вказує на ймовірпість втрати платоспроможності від 80 до 100\%;

Значення $2,77<=Z<1,81$ - на ймовірність банкрутства від 35 до $50 \%$;

Значення $2,99<Z<2,77$ - на ймовірність банкрутства від 15 до $20 \%$;

Значення $Z<=2,99$ вказує на стабільність ситуації, коли ризик відступних зобов'язань є мізерним [7, с. 154$]$.

Змінні в цій моделі відображають різноманітні аспекти роботи компанії

Оскільки економічний зміст факторів суттєво відрізняється внаслідок особливих рис української економіки, пряме застосування моделей Альтмана в умовах України дасть суттєві відхилення прогнозованих значень від реальних.

Наступна модель отримала назву "модель банкрутства Спрінгейта". Використовуючи за основу модель Альтмана, Спрінгейт із дев'ятнадцяти спочатку відібраних для аналізу показників залишив у своїй формулі лише чотири основних коефіцієнта. Формула чотирифакторної моделі Спрінгейта:

$\mathrm{Z}=1,03 \mathrm{~A}+3,07 \mathrm{~B}+0,66 \mathrm{C}+0,4 \mathrm{D}$,

де $\mathrm{A}$ - оборотний капітал / сума активів, $\mathrm{B}$ - нерозподілений прибуток / сума активів, C - прибуток до оподатку вання / поточні зобов'язання, D - прибуток до оподаткування / сума активів.

Оцінка результату: при $Z<0,862$ - висока ймовірність настання неплатоспроможності (оцінка ймовірності втрати платоспроможності).

Точність моделі Спрінгейта, за оцінками фахівців, склала 92,5\% (при обсязі вибірки 40 компаній) [7, с. 141$]$.

Ця модель демонструє необхідний стунінь надійності прогнозу. У ній відсутня галузева та географічна диференціація. Між змінними простежується досить велика взаємозалежність.

На підставі аналізу вищезгаданих методик та дослідження практики їх використання при проведенні процедур оцінювання ризику неадекватного застосування припущення про безперервність діяльності підприємства при підготовці фінансових звітів управлінським персоналом підприсмств можна зробити висновок, що найоптимальнішим шляхом отримання аудиторських доказів, основаних на математичних коефіцієнтах, які відображають погіршення економічного стану підприємства, буде використання методики розрахунку коефіцієнтів швидкої та поточної ліквідності та моделі Спрінгейта.

Висновки. Дослідження питання застосування факторних математичних моделей при оцінюванні та прогнозуванні економічного стану підприємства дозволило дійти висновку про неможливість прямого застосування найбільш поширених моделей через незіставність сучасних економічних умов в Україні і тих країнах, для нідприємств яких вони розроблялись.

Аналіз літературних джерел свідчить, що сучасна наукова база економічного аналізу та аудиту не включає методологію застосування математичних моделей при оцінюванні ризику припинення діяльності з урахуванням особливостей діяльності нідприємств в Україні.

В результаті дослідження виконано аналіз сильних та слабких сторін кожної методики та визначено найбільш оптимальний набір методик, які можуть скласти основу методології застосування математичних моделей виходячи з вимог поточної практики аудиту.

\section{Список використаних джерел}

1. Данилевский Ю. А., Шапигузов С. М. Аудит: учеб. пособ. М.: ИД ФБК-ПРЕСС, $2000.544 \mathrm{c}$.

2. Бланк И. А. Финансовый менеджмент: учебный курс. К.: Ника-центр Эльга, 2002. $528 \mathrm{c}$ 
3. Бутинець Ф. Ф. Економгіний аналіз: навч. посіб. Житомир: ПП “Рута”, 2001. 416 с.

4. Гончарук Я. А., Рудницький В. С. Аудит: навч. посіб. Львів: Світ, 2002. 296 с.

5. Гевко І. Б. Методи прийняття управлінських рішень: підруч. К.: Кондор, 2009. $187 \mathrm{c}$.

6. Давидов Г. М. Аудит: підруч. К.: Ліга. 2004. 336 с.

7. Кіндрацька Г. І., Білик М. С. Економічний аналіз: підруч. К.: Знання, 2008. 487 с.

9. Кулаковська Л. П., Піча Ю. В. Оргапізація і методика аудиту: підруч. К. : Каравела, 2009. $544 \mathrm{c}$.

9. Петрик О. А. Аудит: методологія та оргапізація: моногр. К.: КНЕУ, 2003. 260 с.

10. Проскуріна Н. М. Процедурне забезпечення аудиту. Теорія та практика: моногр. К.: ДП "Інфформ. аналіт. агентство", 2011. 739 с.

C. В. СЕЛИЩЕВ,

кандидат экономических наук, ассистент Национального иентра учета и аудита,

Национальная академия статистики, учета и аудита

\section{Использование математических моделей при проведении аудита соблюдения принципа непрерывности деятельности предприятий}

В статье сделаны обзор и систематизация наиболее распространенных факторных математических моделей анализа финансового состояния предприятия, методик их применения и оценки показателей. Исследована возможность адаптации существующих методик применения математических моделей при проведении аудита соблюдения приниипа непрерывности деятельности предприятий. В результате исследования определен наиболее оптимальный набор математических моделей исходя из требований текуцей практики аудита.

Ключевые слова: предположение о непрерывности, аудит, аудиторский риск, математические модели.

S. V. SELISHCHEV,

PhD (Economics),

Assistant of National Center for Accounting and Audit,

National Academy of Statistics, Accounting and Audit

\section{Using Mathematical Model in Audit of Compliance with the Principle of Continuity of Company Activities}

The article's objective is to study and systematize the existing methods to assess the risk of termination of company activities, and to develop a methodology for applications of factor models in assessment of this risk. Criteria to be met by the method selected for audit are highlighted. The extensive review of the most widespread methods for predicting the financial performance at company level is made: computation of current ratio, computation of acid text ratio, Beaver model, two-factor model of Altman, five-factor model of Altman, Springate model. The study aimed at further development and adaptation of the existing mathematical models for audit of compliance with the principle of continuity of company activities is made. The review of the above mentioned methods and analysis of their applications in the procedures involved in assessing the risk of inadequate use of the assumption on the continuity of company activities in preparing financial reports by company managers allows for the conclusion that the best way to obtain auditor evidence based on mathematical coefficients reflecting the declining economic performance of a company is to apply the methods for computation of current ratio and acid text ratio, and Springate model.

Keywords: assumption on continuity, audit, audit risk, mathematical models.

\section{Посилання на статтю:}

Селіщев С. В. Використання математичних моделей при проведенні аудиту дотримання принщипу безперервності діяльності підприємств // Науковий вісник Національної академії статистики, обліку та аудиту: зб. наук. пр. 2017. №3. С. 42-46. 